\title{
Gas vesicle genes in Planktothrix spp. from Nordic lakes: strains with weak gas vesicles possess a longer variant of gvpC
}

\author{
S. J. Beard, ${ }^{1}$ P. A. Davis, ${ }^{1}$ D. Iglesias-Rodríguez, ${ }^{1}$ O. M. Skulberg ${ }^{2}$ \\ and A. E. Walsby ${ }^{1}$
}

Author for correspondence: A. E. Walsby. Tel: +44 1179287490. e-mail: A.E.Walsby@bristol.ac.uk

\footnotetext{
1 School of Biological Sciences, University of Bristol, Woodland Road, Bristol BS8 1UG, UK

2 Norwegian Institute for Water Research, PO Box 173 Kjelsas, N-0411 Oslo, Norway
}

\begin{abstract}
In cyanobacteria of the genus Planktothrix, there are three length variants of gvpC, the gene that encodes the outer protein of the gas vesicle. Sequence analyses indicated that the three allelic variants of gvpC differ principally in the presence or absence of a $99 \mathrm{nt}$ and a $213 \mathrm{nt}$ section. Strains with the new variant, gvp $\mathrm{C}^{28}$, which encodes a $28 \mathrm{kDa}$ form of GvpC, produce gas vesicles that collapse at the relatively low critical pressure $\left(p_{c}\right)$ of $0.61-0.75 \mathrm{MPa}$. The authors have identified 12 classes of gvp genotypes that differ in the number and arrangement of alternating gvpA-gvpC genes and in the presence of $\Omega C_{\text {, a }}$ fragment of gvpC. The gvp ${ }^{28}$ gene was found to be the most common variant of gvpC amongst 71 strains of Planktothrix isolated from Nordic lakes: 34 strains contained only gvpC ${ }^{28} ; 22$ strains, which possessed only the shorter gvp $^{20}$ gene, produced gas vesicles with a higher $p_{c}$ of 0.76-0.91 $\mathrm{MPa}$; and 15 strains, which possessed both $\mathrm{gvpC}^{20}$ and $\mathrm{gvpC}^{28}$, also produced the stronger gas vesicles. Genotypes with only the $\operatorname{gvpC}^{28}$ genes were more common amongst green Planktothrix strains (33 out of 38 ) than red strains (one out of 33). It is suggested that there is competition between the strains producing the two types of gas vesicles, with the stronger forms favoured in lakes deeper than $60 \mathrm{~m}$, in which the combination of cell turgor pressure and hydrostatic pressure can collapse the weaker gas vesicles. The fact that none of the Nordic lakes are deeper than $67 \mathrm{~m}$ would explain the absence of the gvp $C^{16}$-containing strains that produce even narrower gas vesicles of $p_{c}$ 1.0-1.2 MPa, which are common in the much deeper Lake Zürich.
\end{abstract}

Keywords: cyanobacterial genetics, gas vesicles, Planktothrix

\section{INTRODUCTION}

The possession of gas vesicles is the principal character that distinguishes cyanobacteria in the genus Planktothrix from those that were once classified in the genus Oscillatoria (Anagnostides \& Komàrek, 1988). Gas vesicles provide the buoyancy that enables these organisms to regulate their position in the metalimnion, or float in the epilimnion of lakes. However, during autumnal and vernal lake mixing, cyanobacteria may be

Abbreviations: 33RR, 33-residue repeat; $p_{c^{\prime}}$ critical pressure; $p_{\mathrm{t}^{\prime}}$ turgor pressure; $p_{\mathrm{h}}$, hydrostatic pressure.

The GenBank accession numbers for the new sequences in this paper are AJ253125-253133. circulated to depths at which the hydrostatic pressure causes collapse of their gas vesicles, destroying their buoyancy.

Gas vesicles are constructed from two principal proteins: GvpA is a small, highly conserved protein that forms the ribs of the cylindrical structure (Walker \& Walsby, 1983; Hayes et al., 1986); GvpC is a larger, less conserved protein, which is attached to the outer surface of the structure (Walsby \& Hayes, 1988) and stabilizes it (Hayes et al., 1992). In Calothrix spp. there are two copies of $g \nu p A$, the gene that encodes the rib protein, located upstream of a single copy of $g v p C$, the gene that encodes the outer protein (Tandeau de Marsac et al., 1985; Damerval et al., 1987). The latter contains four partially conserved repeats of $99 \mathrm{nt}$, encoding four 33- 
residue repeats (33RRs) in the protein sequence. In Anabaena flos-aquae there are at least five copies of gvpA in tandem repeat (Hayes \& Powell, 1995) and one copy of $g v p C$, which contains five 99 nt elements (Hayes et al., 1988). It has been suggested that the length of GvpC may influence the width of the gas vesicle as it assembles (Walsby, 1994). In halobacteria, gas vesicle morphology is affected by mutations in $g v p C$ (DasSarma et al., 1994; Offner et al., 1996). Changes in width will affect the critical pressure $\left(p_{c}\right)$ at which the gas vesicle collapses, and this has consequences for gas vesicles of organisms that occur in lakes that mix to different depths (Walsby, 1994).

In Planktothrix spp., two forms of GvpC have been described, one of $16 \mathrm{kDa}$, encoded by $g \nu p \mathrm{C}^{16}$, and one of $20 \mathrm{kDa}$, encoded by $g v p C^{20}$ (Beard et al., 1999). The larger GvpC possesses an additional sequence of 33 amino acids that shows similarity to three other 33residue sections in the molecule. In strains of Planktothrix rubescens isolated from Lake Zürich, Switzerland, the $g v p A$ and $g v p C$ genes alternate in one of three arrangements: genotype GV1 contains $g v p C^{20}$ only; GV2 contains $g v p C^{20}$ and $\Omega C$, an untranslated $72 \mathrm{bp}$ fragment from the $3^{\prime}$-end of $g v p C^{20}$; GV3 contains $g v p C^{16}, g v p C^{20}$ and $\Omega C$ (Beard et al., 1999). Trichomes with genotype $\mathrm{GV} 1$ or $\mathrm{GV} 2$ produce gas vesicles that are wider and weaker $\left(p_{c}=0.86-1.0 \mathrm{MPa}\right)$ than those with GV3 $\left(p_{\mathrm{c}}=1 \cdot 0-1.17 \mathrm{MPa}\right)$ (Bright \& Walsby, 1999). These GV-genotypes can be distinguished by diagnostic PCR using primers complementary to sequences within $g \nu p A$ or $g \nu p C$. This technique can be used to identify the genotype, and hence the $p_{c}$ phenotype, of single trichomes taken from a lake (Beard et al., 1999).

Walsby et al. (1998) showed that during the winter months some Planktothrix trichomes in Lake Zürich are circulated to depths at which the hydrostatic pressure causes collapse of their gas vesicles. After cold winters, when the lake mixes to greater depths, this might lead to natural selection of strains with narrower and stronger gas vesicles, more of which remain buoyant and float upwards to form the spring inoculum. The proportions of strains with stronger gas vesicles can be investigated by PCR analysis of GV-genotypes.

It has been suggested that red strains of Planktothrix may be adapted to the conditions in deeper lakes. An investigation of seven strains revealed that four redcoloured strains possessed gas vesicles that collapsed at $0 \cdot 9-1 \cdot 0 \mathrm{MPa}$, while those in three green-coloured strains collapsed at a pressure of $0.6-0.7 \mathrm{MPa}$ (Utkilen et al., 1985). We report here a survey of the gas-vesicle genotype of 71 strains of Planktothrix, isolated from 21 Nordic lakes ranging in depth from 8 to $67 \mathrm{~m}$. In recent years these strains have been catalogued using the groupings suggested by Skulberg \& Skulberg (1985), on the basis of pigmentation and trichome width: $P$. rubescens group, red forms that contain phycoerythrin (trichomes $<6 \mu \mathrm{m}, P$. prolifica; $>6 \mu \mathrm{m}, P$. rubescens); and $P$. agardhii group, green forms that lack phycoerythrin (trichomes $<6 \mu \mathrm{m}, P$. agardhii; $>6 \mu \mathrm{m}, P$. mougeotii). In this paper we retain the two group names for the different red and green strains, but do not distinguish them further. We report here the discovery, in many Planktothrix strains from Nordic lakes, of a longer variant of the $g v p C$ gene that is correlated with the production of even wider and weaker gas vesicles. We investigated its association with the pigmentation of the strains, and its selection in relation to the depth of lakes in which they occur.

\section{METHODS}

Cultures of Planktothrix spp. The cultures of Planktothrix spp. investigated were those held in the NIVA Collection of Algae (Skulberg \& Skulberg, 1990) that were isolated over the period 1964-1997 from inland waters of Nordic countries (Norway, Sweden, Denmark and Finland) and from one location in the brackish water of the Gulf of Finland. Cultures were established by Skulberg \& Skulberg (1990) from single trichomes using the technique of Rippka (1988), with subsequent purification on agar plates, although the genetic uniformity of the cultures had not been confirmed. Stock cultures were maintained in $\mathrm{Z} 8$ culture medium at $17 \pm 2{ }^{\circ} \mathrm{C}$ under illumination from fluorescent lamps (Philips T1 65 W/33) (Skulberg \& Skulberg, 1990). During subculturing, no special precautions were taken to select the floating trichomes and, as a consequence (Walsby, 1981), some of the cultures contained mainly non-buoyant trichomes. Experimental cultures were grown in the medium of Bright \& Walsby (2000).

Isolation of genomic DNA. Genomic DNA was isolated from Planktothrix cultures as described previously (Beard et al., 1999). Alternatively, the following procedure was used to prepare cell lysates that were also suitable templates for diagnostic PCR. A $1 \mathrm{ml}$ sample from a dense culture (pressurized at 1.4 MPa to collapse the gas vesicles) was mixed with proteinase $\mathrm{K}\left(0 \cdot 2 \mathrm{mg} \mathrm{ml}^{-1}\right)$ and incubated for $15 \mathrm{~min}$ at $55^{\circ} \mathrm{C}$, followed by $15 \mathrm{~min}$ at $80^{\circ} \mathrm{C}$. After a brief centrifugation, the supernatant was collected, and 5-10 $\mu$ l used in subsequent PCR amplifications. The cell lysates were stored at $4{ }^{\circ} \mathrm{C}$ for up to one year.

PCR amplification and sequencing. Purified genomic DNA preparations or cell lysates were used as templates in PCR amplifications with the Planktothrix-specific gup primers described in Table 1 and by Beard et al. (1999). All reactions were subjected to an initial denaturation step of $94^{\circ} \mathrm{C}$ for $4 \mathrm{~min}$, followed by 30 cycles of amplification $\left(94^{\circ} \mathrm{C}\right.$, $45 \mathrm{~s}$; primer-specific annealing temperature, $1 \mathrm{~min} ; 72^{\circ} \mathrm{C}$, $1 \mathrm{~min}$ ), and a final extension step of $72{ }^{\circ} \mathrm{C}$ for $5 \mathrm{~min}$. The annealing temperatures used for the diagnostic PCR amplifications were as follows: $65^{\circ} \mathrm{C}\left(4\right.$ cycles) followed by $70{ }^{\circ} \mathrm{C}$ (26 cycles) for GVPA1 and GVPA2; $65^{\circ} \mathrm{C}$ for GVPC1B, GVPC9 and GVPC11; $53{ }^{\circ} \mathrm{C}$ for GVP 24 , GVP 25 and GVPC10. PCR products were purified and sequenced as described previously (Beard et al., 1999).

Measurement of gas vesicle critical pressures. The $p_{\mathrm{c}}$ distributions of gas vesicles in Planktothrix trichomes were determined with a pressure nephelometer (Walsby, 1973). Measurements were made on $2 \mathrm{ml}$ samples of cultures mixed with $2 \mathrm{ml} 1 \cdot 0 \mathrm{M}$ sucrose solution, buffered with $5 \mathrm{mM}$ $\mathrm{K}_{2} \mathrm{HPO}_{4}$, to remove cell turgor pressure. The means and standard deviations of the $p_{\mathrm{c}}$ distributions were calculated from triplicate measurements using the procedure of Walsby \& Bleything (1988). 
Table 1. New oligonucleotide primers used for PCR amplification and sequence analysis of the gvp genes in Planktothrix spp.

\begin{tabular}{|c|c|c|c|c|c|}
\hline \multirow{3}{*}{$\begin{array}{l}\text { Primer } \\
\text { GVPC1B }\end{array}$} & \multirow{3}{*}{$\begin{array}{l}\text { Sequence }\left(5^{\prime} \text { to } 3^{\prime}\right)^{*} \\
\text { CTCCCCCAAACTGTCTG }\end{array}$} & \multirow{3}{*}{$\begin{array}{c}\text { Direction } \uparrow \\
\mathrm{R}\end{array}$} & \multicolumn{3}{|c|}{ Target site $\neq$} \\
\hline & & & \multirow{2}{*}{$\begin{array}{l}\text { Gene or spacer } \\
g v p C\end{array}$} & \multicolumn{2}{|c|}{ Position } \\
\hline & & & & $443-421$ & $(\mathrm{AJ} 253125)$ \\
\hline GVPC9 & ACGCCAACAGGGAGTTCAAGAACG & $\mathrm{F}$ & $g v p C$ & $42-65$ & (AJ253125) \\
\hline GVPC10 & GCTGTTTCTGATAATTRGCTA & $\mathrm{R}$ & $g v p C$ & $187-167$ & (AJ253125) \\
\hline GVPC11 & GGCTACCCACAAACGCTCGGTG & $\mathrm{R}$ & $g v p C^{28}$ & $234-213$ & (AJ253131) \\
\hline GVPC12 & TTATCCCTGGGGTTGATCCAG & $\mathrm{R}$ & $g v p C$ & $522-502$ & (AJ253125) \\
\hline GVPC13 & TAGATGATCAAGAATCTCGACAGG & $\mathrm{F}$ & $g v p C^{28}$ & $137-160$ & (AJ253131) \\
\hline GVP $\Omega 4$ & CAAGCCATTCCCCATTCTAT & $\mathrm{F}$ & $g v p A-\Omega C$ spacer & $217-236$ & (AJ253126) \\
\hline GVP $\Omega 5$ & GCTTGGGATCGGCTTTGG & $\mathrm{R}$ & $g v p A-\Omega C$ spacer & $221-204$ & (AJ253126) \\
\hline
\end{tabular}

$* \mathrm{R}=\mathrm{A}$ or $\mathrm{G}$.

†Direction indicates the primer orientation, forward $(\mathrm{F})$ or reverse $(\mathrm{R})$.

$\ddagger$ Position of target site is given with respect to the relevant sequence deposited in the GenBank database (accession numbers indicated in parentheses).

\section{RESULTS}

\section{Identification of a new variant of $g v p C$}

In previous studies on Planktothrix strains isolated from Lake Zürich we identified three gas vesicle genotypes based upon different combinations of the three amplification products (1-3 in Fig. 1a) obtained using the
gvpA-specific primers GVPA1 and GVPA2 (Beard et al., 1999; Fig. 1a). A product of length 595 bp indicated the presence of $\Omega C$, the $965 \mathrm{bp}$ product indicated $g v p C^{16}$, and the $1064 \mathrm{bp}$ product indicated $g v p \mathrm{C}^{20}$, each located between adjacent copies of gvpA. Many of the Planktothrix strains in the NIVA collection gave a new product, of $1.3 \mathrm{kbp}$, when genomic DNA was used as a template (a)

1.

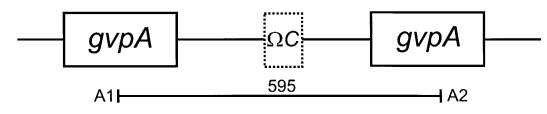

2.

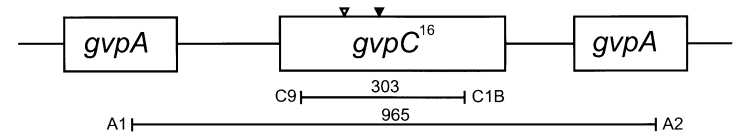

3.

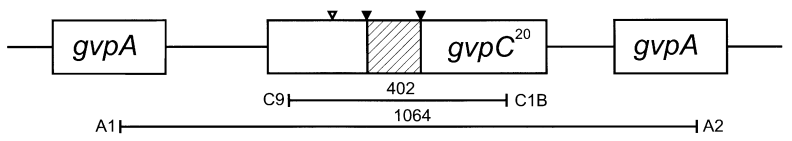

4.

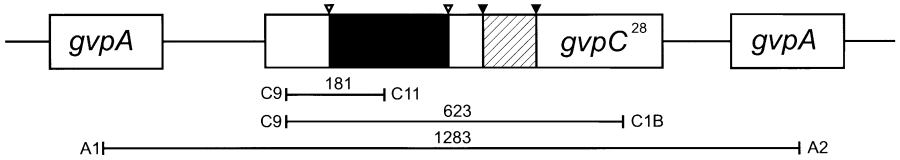

(b)

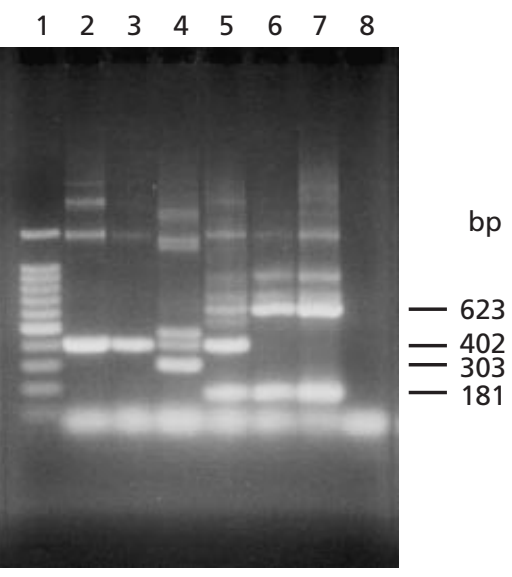

Fig. 1. Diagnostic $P C R$ amplifications used to distinguish gas vesicle genotypes of Planktothrix spp. (a) The four different gvpA-gvpC-gvpA gene clusters (1-4) and the PCR products generated by amplification with Planktothrix-specific gvpA and gvpC primers. The boxed regions indicate the gvpA and gvpC ORFs; the box drawn with broken lines represents the $72 \mathrm{bp}$ region $(\Omega C)$ identical to the $3^{\prime}$ end of $g v p C$. The hatched area is the $99 \mathrm{nt}$ region (in both $g v p C^{20}$ and $g v p C^{28}$ ) and the black area is the $219 \mathrm{nt}$ region (in $\mathrm{gvpC}^{28}$ ). The locations of the $99 \mathrm{nt}$ and $219 \mathrm{nt}$ regions are indicated by filled and open triangles, respectively. The lines under each gene cluster indicate the PCR products (in bp) obtained using the gvpAspecific primers GVPA1 and GVPA2, and the gvpC-specific primers GVPC1B, GVPC9 and GVPC11 (the prefix GVP is omitted). (b) Electrophoretic separation on an agarose gel $(1.5 \%, \mathrm{w} / \mathrm{v})$ of the products obtained by amplification of $g v p C$ using primers GVPC1B, GVPC9 and GVPC11. Lanes: 1, 100 bp ladder (Promega); 2, P. rubescens Pla 9303 (GV1); 3, P. rubescens Pla 9316 (GV2); 4, P. rubescens Pla 9401 (GV3); 5, P. rubescens PCC 7821 (GV4); 6, P. agardhii CYA 29 (GV5); 7, P. agardhii CYA 137 (GV6); 8, no-template control. 


\section{(a) P. rubescens PCC 7821, GV4}
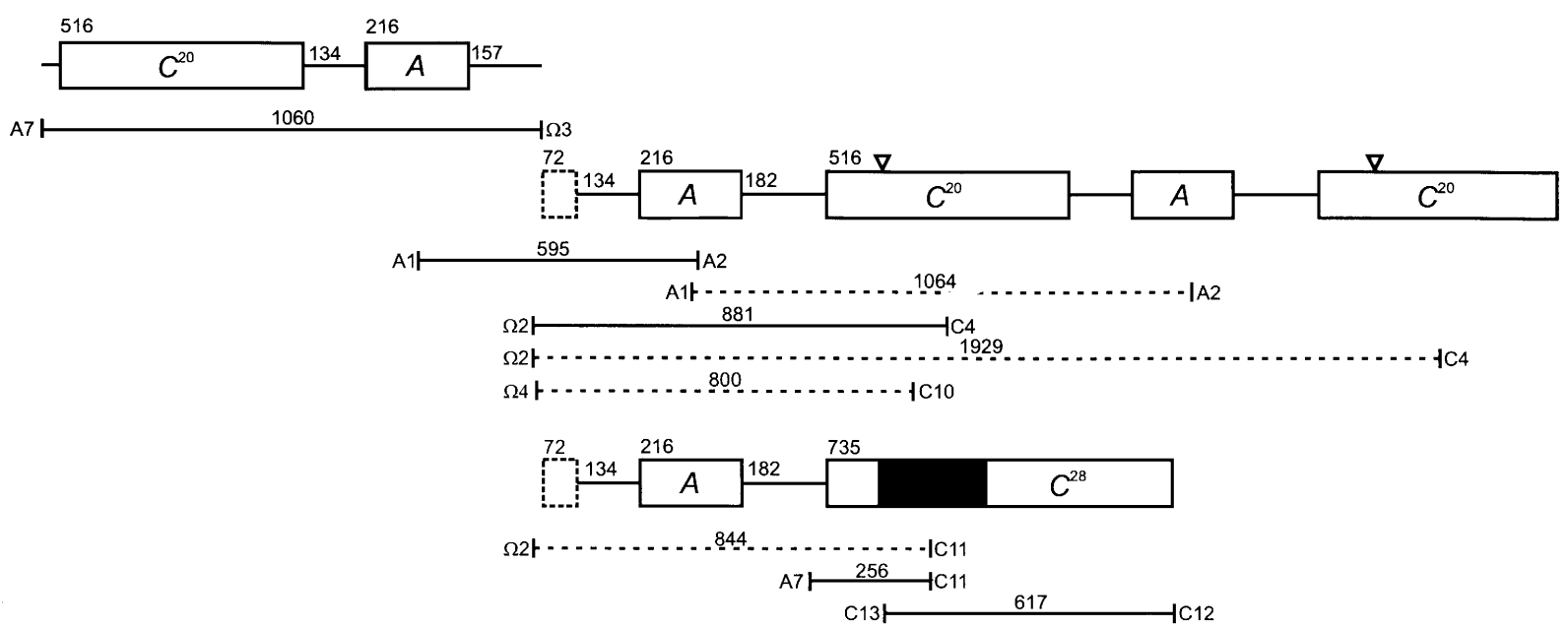

(b) P.agardhii CYA 29, GV5

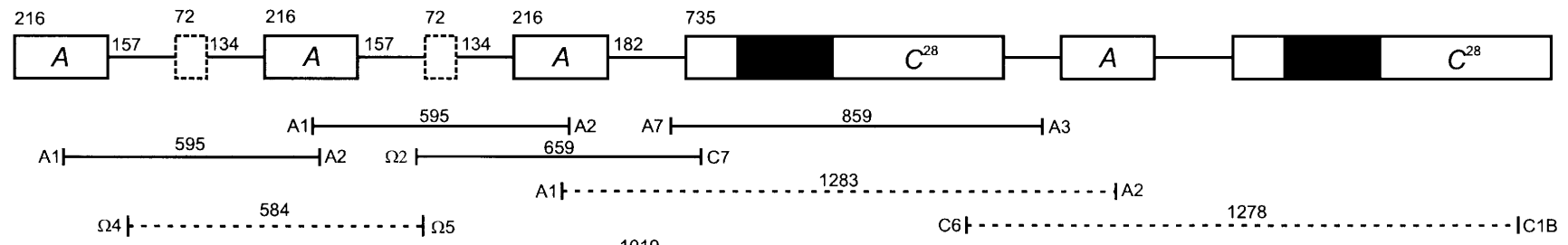

$\Omega 4+\ldots \ldots+\ldots+1019$

(c) P.agardhii CYA 137, GV6

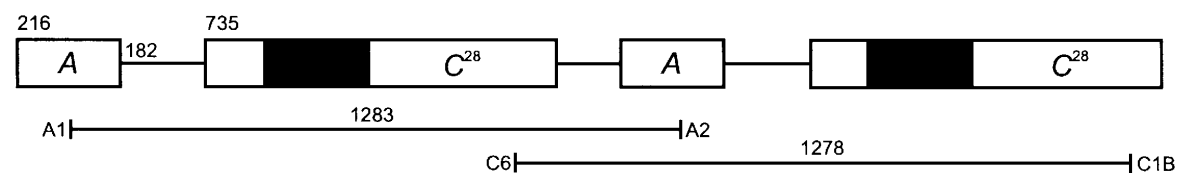

Fig. 2. Arrangements of gas vesicle genes gvpA and gvpC in Planktothrix strains (a) $P$. rubescens PCC 7821 (GV4), (b) $P$. agardhii CYA 29 (GV5) and P. agardhii CYA 137 (GV6). The boxed regions indicate ORFs; those drawn with broken lines indicate the $\Omega C$ region. The black area represents the $219 \mathrm{bp}$ region present in $g v p C^{28}$, but absent in $g v p C^{20}$ (at the position indicated by an open triangle). Lines underneath each gene arrangement represent the products obtained by PCR using the primers indicated at each end (the prefix GVP is omitted). The sequences of the PCR products shown as unbroken lines have been given the GenBank database accession numbers AJ253125-253133. Broken lines indicate PCR products whose sequence has not been determined; the lengths given are those predicted from the lengths of the corresponding sequenced regions. The lengths of ORFs, intergenic regions and PCR products are given in bp.

for amplification with these primers. The nucleotide sequence of this product revealed a $735 \mathrm{bp}$ ORF between the $3^{\prime}$-end of one gvpA and the $5^{\prime}$-end of a second $g v p A$. The first $120 \mathrm{bp}$ and last $396 \mathrm{bp}$ of the ORF are identical to the $5^{\prime}$ - and $3^{\prime}$-ends, respectively, of $g v p C^{20}$; there is an additional 219 bp segment between these sections. This ORF is a third variant of $g v p C$, which, from the size of its inferred translation product $(28 \mathrm{kDa})$, can be designated $g v p C^{28}$. We identified three new classes of gas vesicle genotype in the NIVA collection: GV4, containing $g v p C^{28}$ together with $g v p C^{20}$ and $\Omega C$; GV5, containing $g v p C^{28}$ and $\Omega C$; GV6, containing only $g \nu p C^{28}$.

\section{Development of a diagnostic PCR for the different variants of $g v p C$}

The three allelic variants of $g v p C\left(g \nu p C^{16}, g v p C^{20}\right.$ and $g v p C^{28}$ ) in Planktothrix spp. can also be distinguished by PCR assays that are independent of flanking gvpAs (Fig. 1a). The forward primer GVPC9 and reverse primer GVPC1B (Table 1) are complementary to the 
conserved sequences at the $5^{\prime}$ - and $3^{\prime}$-ends, respectively, of the three different $g v p C$ ORFs. Amplification between GVPC9 and GVPC1B generates products of the following lengths: $303 \mathrm{bp}$ from $g v p \mathrm{C}^{16}, 402 \mathrm{bp}$ from $g v p C^{20}$ and $623 \mathrm{bp}$ from $g v p C^{28}$ (Fig. 1). Due to the preferential amplification of the $402 \mathrm{bp}$ product in strains containing both $g \nu p C^{20}$ and $g \nu p C^{28}$ (genotype GV4), the $623 \mathrm{bp}$ product was sometimes very faint (Fig. $1 \mathrm{~b}$, lane 5). For this reason, a second reverse primer, GVPC11 (Table 1), which is complementary to a sequence within the $219 \mathrm{bp}$ region that is unique to $g v p C^{28}$, was included in the PCR assays: amplification between GVPC9 and GVPC11 generated a product of $181 \mathrm{bp}$ from $g v p C^{28}$ (Fig. 1). The higher molecular mass products ( $>623 \mathrm{bp}$ ) observed in Fig. 1(b) (lanes 2-7) represent either the products generated by amplification between subadjacent copies of $g v p C$ or heteroduplexes formed by hybridization between variants of $g \nu p C$ (Beard et al., 1999).

\section{Arrangement and sequence of gas vesicle gene clusters}

The arrangement and sequence of the gvpA-C gene clusters in type strains of the three new GV genotypes were determined by the analysis of various PCR products (Fig. 2).

Genotype GV4. The arrangement of the $g v p A-g v p C^{20}$ repeats in P. rubescens PCC 7821 is similar to that found in P. rubescens strain Pla 9316 (GV2) from Lake Zürich (Beard et al., 1999). Indeed, the sequences of two gvpA ORFs, two gvpC ${ }^{20}$ ORFs (one complete, one partial), the $\Omega C$ region, and all intergenic regions were identical to the corresponding regions in strain Pla 9316. P. rubescens PCC 7821 was also found to contain $g v p C^{28}$ although we were unable to amplify the complete ORF. We were, however, able to amplify the first $709 \mathrm{nt}$ of the $735 \mathrm{nt} g v p \mathrm{C}^{28} \mathrm{ORF}$ as two overlapping PCR products using $g v p C^{28}$-specific forward and reverse primers GVPC13 and GVPC11 (Fig. 2). On either side of the additional $219 \mathrm{bp}$ segment, the sequence of $g v p C^{28}$ is identical to that of $g v p C^{20}$ in PCC 7821, although ambiguities at two positions indicate that this strain contains at least two allelic variants of $g v p C^{28}$. Four subclasses of genotype GV4 that differed in the arrangement of $g v p C^{20}, g \nu p C^{28}$ and $\Omega C$ were subsequently identified in strains of the NIVA Collection (Table 2).

Genotype GV5. The gvpA-C gene cluster in $P$. agardhii CYA 29 consists of two consecutive copies of a $g v p A-\Omega C$ repeat followed by two copies of a gvpA-gvp$C^{28}$ repeat (Fig. 2). The sequence of $g v p A$ is identical to that in $P$. rubescens PCC 7821, but there are three substitutions in the $g v p A-\Omega C$ spacer and one substitution in the $\Omega C-$ gvpA spacer. The sequence of $g \nu p C^{28}$ shows three differences from that of $g v p C^{28}$ in $P$. rubescens PCC 7821. Two subclasses of genotype GV5 were identified in the NIVA strains: one with a single copy of $\Omega C$ (GV5a) and one with two copies (GV5b) (Table 2).

Griffiths (1992) isolated from the gas vesicles of strain CYA 29 an SDS-soluble protein whose mobility in SDS-
PAGE indicated a molecular mass of $28 \cdot 8 \mathrm{kDa}$, close to the size calculated for the product of the $g \nu p C^{28}$ gene. [The $21.7 \mathrm{kDa}$ size for the product given by Griffiths et al. (1992) was in error.]

Genotype GV6. P. agardhii CYA 137 was found to contain two consecutive copies of the $g v p A-g v p C^{28}$ repeat (Fig. $2)$. The sequence of the complete $g v p C^{28}$ ORF shows two differences from that in $P$. rubescens PCC 7821. The sequences of two gvpAs and intergenic regions are identical to those in PCC 7821, except for one substitution in the $g v p C-g v p A$ spacer. The partial sequence of the downstream copy of $g v p C^{28}$ differs from the upstream copy in three positions (see below).

\section{Sequence differences in the $g v p C$ variants}

The 99 nt section that distinguishes $g \nu p C^{20}$ from $g \nu p C^{16}$ encodes a 33 amino acid residue section that can be considered to be a cryptic 33RR as it aligns with three other 33-residue sections with which it shows some sequence similarity (Beard et al., 1999). The additional $219 \mathrm{nt}$ section that distinguishes $g v p C^{28}$ from $g v p C^{20}$ encodes an additional section of 73 amino acid residues. We have looked for evidence of 33RRs within this sequence: the sequence ER --VA-Q---QL occurs both at the $\mathrm{C}$-terminal end of this segment and 33 residues before the end. Elsewhere, there is little sequence similarity.

Apart from the additional $99 \mathrm{nt}$ and $219 \mathrm{nt}$ sections that distinguish the variants $g v p C^{16}, g v p C^{20}$ and $g v p C^{28}$, these genes show only a few single-nucleotide differences. These differences are restricted to six positions, which occur in regions common to all three of the variants. Three of these differences affect the encoded amino acid, as follows: Arg or Thr at residue 125, and Pro or Ser at residues 223 and 228 (positions given with respect to the sequence of $\left.\mathrm{GvpC}^{28}\right)$.

\section{Survey of GV-genotypes of other Planktothrix strains in the NIVA collection}

In 69 of the 72 Planktothrix strains in the NIVA collection isolated from lakes in Nordic countries, the GV-genotypes were determined, using three sets of PCR amplifications.

(1) The diagnostic PCR for gvpC (Fig. 1) was used to distinguish between genotypes GV1/2, GV3, GV4 and GV5/6.

(2) Amplification with primers GVPA1 and GVPA2 was used to screen for the presence of the $\Omega C$ region between adjacent copies of gvpA (Beard et al., 1999). This PCR was used to distinguish between genotypes GV1 and GV2, and between GV5 and GV6.

(3) Subclasses of genotypes GV2, GV4 and GV5, which differ according to the location and number of copies of $\Omega C$, were identified by amplification with primers GVP $\Omega 4$, GVP $\Omega 5$ and GVPC10 (Table 1). The forward and reverse primers, GVP $\Omega 4$ and GVP $\Omega 5$, respectively, are specific to the unique sequence immediately upstream of $\Omega C$, and are complementary to one another at 
Table 2. Arrangement of gvp genes in the different GV-genotypes of Planktothrix spp. and the products of diagnostic PCRs

The gene arrangements were determined by sequencing PCR products or by comparing the observed and predicted sizes of PCR products. The gup gene orders shown in parentheses may in some cases overlap (e.g. GV4b, GV4c), but in other cases (e.g. GV4a) they cannot. BC, Bristol Collection.

\begin{tabular}{|c|c|c|c|c|c|c|c|c|c|c|c|}
\hline \multirow[t]{3}{*}{ Genotype } & \multirow[t]{3}{*}{ Type strain } & \multirow[t]{3}{*}{$g v p$ gene order } & \multicolumn{8}{|c|}{ Products of diagnostic PCRs/bp } & \multirow{3}{*}{$\begin{array}{l}\text { NIVA Planktothrix } \\
\text { strains }\end{array}$} \\
\hline & & & \multicolumn{3}{|c|}{$\mathrm{C} 1 \mathrm{~B} / \mathrm{C} 9 / \mathrm{C} 11$} & \multirow{2}{*}{$\begin{array}{c}\mathrm{A} 1 / \mathrm{A} 2 \\
595 \\
\Omega C\end{array}$} & \multicolumn{4}{|c|}{$\Omega 4 / \Omega 5 / \mathrm{C} 10$} & \\
\hline & & & $\begin{array}{l}181 \\
C^{28}\end{array}$ & $\begin{array}{l}303 \\
C^{16}\end{array}$ & $\begin{array}{r}402 \\
C^{20}\end{array}$ & & $\begin{array}{c}584 \\
\Omega C-A-\Omega C\end{array}$ & $\begin{array}{c}701 \\
\Omega C-A-C^{16}\end{array}$ & $\begin{array}{c}800 \\
\Omega C-A-C^{20}\end{array}$ & $\begin{array}{c}1019 \\
\Omega C-A-C^{28}\end{array}$ & \\
\hline GV1 & Pla 9303 & $A-C^{20}-A-C^{20}$ & & & + & & & & & & \\
\hline GV2a & Pla 9316 & $A-C^{20}-A-\Omega C-A-C^{20}-A-C^{20}$ & & & + & + & & & + & & $\begin{array}{l}\text { Red: CYA 13, 24, 37/1, } \\
37 / 2,37 / 4,55,73, \\
89 / 3,90,97 / 3,97 / 4, \\
\text { 108, 151. Green: CYA } \\
88 / 1,88 / 2,88 / 3,91, \\
127\end{array}$ \\
\hline GV2b & Pla 9731 & $A-C^{20}-A-\Omega C-A-\Omega C-A-C^{20}-A-C^{20}$ & & & + & + & + & & + & & $\begin{array}{l}\text { Red: CYA 89/1, 89/4, } \\
97 / 1,97 / 5\end{array}$ \\
\hline GV3a & Pla 9401 & $A-C^{16}-A-\Omega C-A-C^{16}-A-C^{16}-A-C^{20}$ & & + & + & + & & + & & & \\
\hline GV3b & Pla 9736 & $A-C^{16}-A-\Omega C-A-\Omega C-A-C^{16}-A-C^{16}-A-C^{20}$ & & + & + & + & + & + & & & \\
\hline GV4a & PCC 7821 & $\left(C^{20}-A-\Omega C-A-C^{20}-A-C^{20}\right)\left(\Omega C-A-C^{28}\right)$ & + & & + & + & & & + & + & $\begin{array}{l}\text { Red: PCC 7821, CYA } \\
85,89 / 5\end{array}$ \\
\hline GV5a & CYA 126 & $A-\Omega C-A-C^{28}-A$ & + & & & + & & & & + & $\begin{array}{l}\text { Red: CYA } 87 . \text { Green: } \\
\text { CYA } 12,15,21,30,34 \text {, } \\
64 / 4,64 / 6,86,56 / 1, \\
56 / 3,117 / 3,117 / 4, \\
126,263 / 2\end{array}$ \\
\hline GV5b & CYA 29 & $\Omega C-A-\Omega C-A-C^{28}-A-C^{28}$ & + & & & + & + & & & + & $\begin{array}{l}\text { Green: CYA 11, } 29 \\
\text { (BC), 64/3, 64/5, 116, } \\
278,393,394,397\end{array}$ \\
\hline GV6 & CYA 137 & $A-C^{28}-A-C^{28}$ & + & & & & & & & & $\begin{array}{l}\text { Green: CYA 9, 10, } 29 \\
\text { (NIVA), 59, 64/1, 65, } \\
133,137,229,299\end{array}$ \\
\hline
\end{tabular}


Table 3. Mean $p_{c}$ values of gas vesicles in Planktothrix strains with different GV-genotypes

The $p_{\mathrm{c}}$ is related to the combination of turgor pressure $\left(p_{\mathrm{t}}=0.2 \mathrm{MPa}\right)$ and hydrostatic pressure $\left(p_{\mathrm{h}}\right)$ at the maximum depth of the lake from which the strain was isolated. BC, Bristol Collection.

\begin{tabular}{|c|c|c|c|c|c|c|c|}
\hline \multirow{2}{*}{$\begin{array}{l}\text { GV- } \\
\text { genotype }\end{array}$} & \multirow{2}{*}{$\begin{array}{l}\text { CYA } \\
\text { strain }\end{array}$} & \multirow[t]{2}{*}{ Lake or locality } & \multicolumn{2}{|c|}{ Geographical position } & \multirow{2}{*}{$\begin{array}{c}\text { Max. } \\
\text { depth/m }\end{array}$} & \multirow[t]{2}{*}{ Max. $p / \mathrm{MPa}$} & \multirow{2}{*}{$\begin{array}{l}\text { Mean } \boldsymbol{p}_{\mathrm{c}} \\
(\mathrm{SD}) / \mathrm{MPa}\end{array}$} \\
\hline & & & $\mathbf{N}$ & E & & & \\
\hline \multicolumn{8}{|c|}{ P. rubescens group } \\
\hline \multirow[t]{4}{*}{$2 a$} & 24 & Levrasjön & $56^{\circ} 04^{\prime}$ & $14^{\circ} 28^{\prime}$ & 15 & $0 \cdot 35$ & $0.79(0 \cdot 13)$ \\
\hline & 73 & Kolbotnvatnet & $59^{\circ} 48^{\prime}$ & $10^{\circ} 34^{\prime}$ & 18 & $0 \cdot 38$ & $0 \cdot 90(0 \cdot 18)$ \\
\hline & 151 & Almend Sø & $56^{\circ} 12^{\prime}$ & $9^{\circ} 29^{\prime}$ & 20 & $0 \cdot 40$ & $0 \cdot 88(0 \cdot 15)$ \\
\hline & 108 & Mälaren & $59^{\circ} 28^{\prime}$ & $17^{\circ} 28^{\prime}$ & 64 & $0 \cdot 83$ & $0 \cdot 91(0 \cdot 18)$ \\
\hline \multirow[t]{2}{*}{$2 b$} & $97 / 1$ & Steinsfjorden & $60^{\circ} 04^{\prime}$ & $10^{\circ} 19^{\prime}$ & 24 & $0 \cdot 44$ & $0 \cdot 81(0 \cdot 20)$ \\
\hline & $89 / 1$ & Ören & $58^{\circ} 25^{\prime}$ & $16^{\circ} 01^{\prime}$ & 25 & $0 \cdot 45$ & $0 \cdot 82(0 \cdot 15)$ \\
\hline $4 a$ & $89 / 5$ & Ören & $58^{\circ} 25^{\prime}$ & $16^{\circ} 01^{\prime}$ & 25 & $0 \cdot 45$ & $0.78(0 \cdot 19)$ \\
\hline $4 b$ & 18 & Gjersjøen & $59^{\circ} 47^{\prime}$ & $10^{\circ} 47^{\prime}$ & 64 & $0 \cdot 83$ & $0.88(0 \cdot 21)$ \\
\hline $4 c$ & 35 & Kolbotnvatnet & $59^{\circ} 48^{\prime}$ & $10^{\circ} 34^{\prime}$ & 18 & $0 \cdot 38$ & $0.85(0.23)$ \\
\hline \multirow[t]{4}{*}{$4 d$} & 128 & Långsjön & $60^{\circ} 15^{\prime}$ & $19^{\circ} 55^{\prime}$ & 15 & $0 \cdot 35$ & $0.76(0 \cdot 14)$ \\
\hline & 395 & Stovivatnet & $59^{\circ} 55^{\prime}$ & $10^{\circ} 27^{\prime}$ & 15 & $0 \cdot 35$ & $0.86(0 \cdot 21)$ \\
\hline & 402 & Steinsfjorden & $60^{\circ} 04^{\prime}$ & $10^{\circ} 19^{\prime}$ & 24 & $0 \cdot 44$ & $0.82(0 \cdot 22)$ \\
\hline & 129 & Vesijärvi & $61^{\circ} 19^{\prime}$ & $25^{\circ} 00^{\prime}$ & 40 & 0.59 & $0.82(0 \cdot 17)$ \\
\hline $5 a$ & 87 & Levrasjön & $56^{\circ} 04^{\prime}$ & $14^{\circ} 28^{\prime}$ & 15 & $0 \cdot 35$ & $0 \cdot 71(0 \cdot 15)$ \\
\hline \multicolumn{8}{|c|}{ P. agardhii group } \\
\hline \multirow[t]{3}{*}{$2 a$} & $88 / 1$ & Ören & $58^{\circ} 25^{\prime}$ & $16^{\circ} 01^{\prime}$ & 25 & $0 \cdot 45$ & $0 \cdot 81(0 \cdot 21)$ \\
\hline & 127 & Vesijärvi & $61^{\circ} 19^{\prime}$ & $25^{\circ} 00^{\prime}$ & 40 & $0 \cdot 59$ & $0 \cdot 85(0 \cdot 18)$ \\
\hline & 91 & Mälaren & $59^{\circ} 28^{\prime}$ & $17^{\circ} 28^{\prime}$ & 64 & $0 \cdot 83$ & $0.92(0 \cdot 19)$ \\
\hline \multirow[t]{8}{*}{$5 a$} & $64 / 4$ & Helgetjernet & $59^{\circ} 29^{\prime}$ & $11^{\circ} 40^{\prime}$ & 8 & $0 \cdot 28$ & $0.62(0 \cdot 13)$ \\
\hline & 126 & Långsjön & $60^{\circ} 15^{\prime}$ & $19^{\circ} 55^{\prime}$ & 15 & $0 \cdot 35$ & $0.75(0 \cdot 10)$ \\
\hline & 15 & Kolbotnvatnet & $59^{\circ} 48^{\prime}$ & $10^{\circ} 34^{\prime}$ & 18 & $0 \cdot 38$ & $0.68(0 \cdot 11)$ \\
\hline & $56 / 1$ & Steinsfjorden & $60^{\circ} 04^{\prime}$ & $10^{\circ} 19^{\prime}$ & 24 & $0 \cdot 44$ & $0.70(0.09)$ \\
\hline & $263 / 2$ & Vestvatnet & $59^{\circ} 21^{\prime}$ & $11^{\circ} 03^{\prime}$ & 28 & 0.47 & $0.66(0.08)$ \\
\hline & 30 & Fröylandsvatnet & $58^{\circ} 45^{\prime}$ & $5^{\circ} 40^{\prime}$ & 29 & $0 \cdot 48$ & $0.68(0.13)$ \\
\hline & $117 / 4$ & Gjersjøen & $59^{\circ} 47^{\prime}$ & $10^{\circ} 47^{\prime}$ & 64 & $0 \cdot 83$ & $0.69(0 \cdot 10)$ \\
\hline & 21 & Gulf of Finland & $59^{\circ} 35^{\prime}$ & $23^{\circ} 11^{\prime}$ & 67 & $0 \cdot 86$ & $0.68(0.15)$ \\
\hline \multirow[t]{4}{*}{$5 b$} & 116 & Årungen & $59^{\circ} 41^{\prime}$ & $10^{\circ} 45^{\prime}$ & 13 & $0 \cdot 33$ & $0.66(0.09)$ \\
\hline & 11 & Akersvatnet & $59^{\circ} 15^{\prime}$ & $10^{\circ} 20^{\prime}$ & 14 & $0 \cdot 34$ & $0.61(0 \cdot 15)$ \\
\hline & 397 & Stovivatnet & $59^{\circ} 55^{\prime}$ & $10^{\circ} 27^{\prime}$ & 15 & $0 \cdot 35$ & $0.67(0.14)$ \\
\hline & $29(\mathrm{BC})$ & Gjersjøen & $59^{\circ} 47^{\prime}$ & $10^{\circ} 47^{\prime}$ & 64 & $0 \cdot 83$ & $0.68(0 \cdot 10)$ \\
\hline \multirow[t]{10}{*}{6} & $64 / 1$ & Helgetjernet & $59^{\circ} 29^{\prime}$ & $11^{\circ} 40^{\prime}$ & 8 & $0 \cdot 28$ & $0.68(0.15)$ \\
\hline & 229 & Östra Kyrksundet & $60^{\circ} 16^{\prime}$ & $20^{\circ} 10^{\prime}$ & 10 & $0 \cdot 30$ & $0.72(0 \cdot 11)$ \\
\hline & 137 & Steinsfjorden & $60^{\circ} 04^{\prime}$ & $10^{\circ} 19^{\prime}$ & 24 & $0 \cdot 44$ & $0.68(0.09)$ \\
\hline & 299 & Kalvsjøtjernet & $60^{\circ} 17^{\prime}$ & $10^{\circ} 33^{\prime}$ & 26 & $0 \cdot 46$ & $0.66(0 \cdot 16)$ \\
\hline & 9 & Fröylandsvatnet & $58^{\circ} 45^{\prime}$ & $5^{\circ} 40^{\prime}$ & 29 & $0 \cdot 48$ & $0.63(0 \cdot 18)$ \\
\hline & 133 & Øgderen & $58^{\circ} 46^{\prime}$ & $11^{\circ} 25^{\prime}$ & 35 & 0.54 & $0.68(0 \cdot 11)$ \\
\hline & 59 & Jarenvatnet & $60^{\circ} 23^{\prime}$ & $10^{\circ} 33^{\prime}$ & 38 & 0.57 & $0.63(0 \cdot 17)$ \\
\hline & 65 & Vansjø & $59^{\circ} 27^{\prime}$ & $10^{\circ} 45^{\prime}$ & 41 & $0 \cdot 60$ & $0.66(0 \cdot 13)$ \\
\hline & 10 & Gjersjøen & $59^{\circ} 47^{\prime}$ & $10^{\circ} 47^{\prime}$ & 64 & $0 \cdot 83$ & $0.69(0.08)$ \\
\hline & 29 (NIVA) & Gjersjøen & $59^{\circ} 47^{\prime}$ & $10^{\circ} 47^{\prime}$ & 64 & $0 \cdot 83$ & $0.72(0 \cdot 14)$ \\
\hline
\end{tabular}

their $5^{\prime}$ ends. These primers generated a 584 bp product by amplification between two copies of $\Omega C$ located either side of a copy of $g \nu p A$. A second reverse primer GVPC10 (complementary to a region within $g v p C$ ) was included in this PCR to amplify the region between $\Omega C$

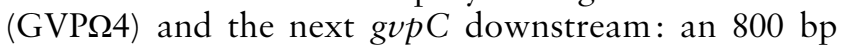
product indicated the gene arrangement $\Omega C-g v p A-$ $g v p C^{20}$, whereas a 1019 bp product indicated the arrangement $\Omega C-g \nu p A-g \nu p C^{28}$.
P. rubescens group. Of 33 red-coloured strains of Planktothrix, 17 were of genotype GV2, 15 were of genotype GV4 and one (strain CYA 87 from Lake Levrasjön) was of genotype GV5a (Table 2). In five of seven cases where there was more than one isolate from a lake, the genotypes differed: both GV2 and GV5 occurred in Lake Levrasjön; GV2 and GV4 occurred in Lakes Kolbotnvatnet, Ören and Steinsfjorden; and three subclasses of GV4 occurred in Lake Gjersjøen. There was a 


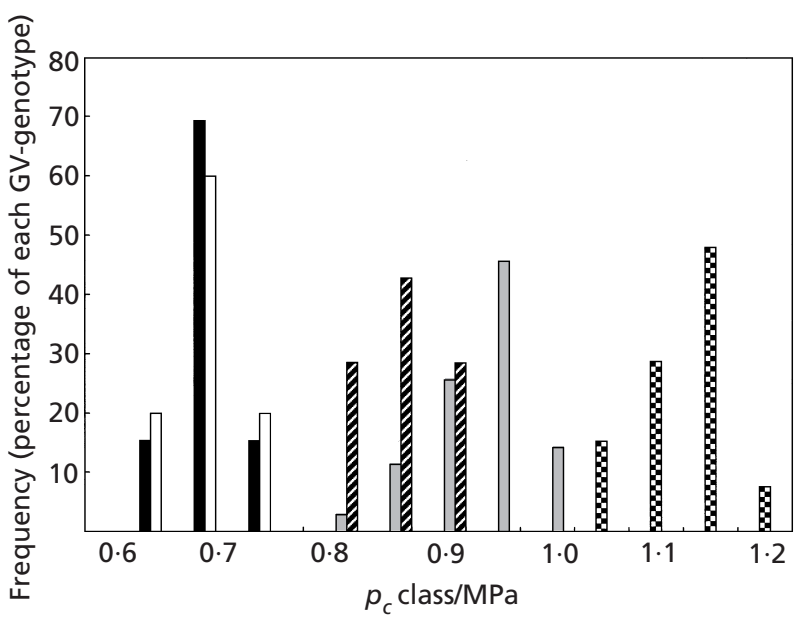

Fig. 3. Histogram of the frequency of mean $p_{c}$ values of gas vesicles in Planktothrix strains from the NIVA Culture Collection of Algae identified by GV-genotype: $\square, G V 2, \square, G V 4 ; \mathbf{\square}, G V 5$; $\square$, GV6. Also indicated is the $p_{c}$ distribution in strains of genotype GV3 isolated from Lake Zürich (⿴囗口). Frequencies are given as percentages of the total number of strains in each genotype.

discrepancy in the genotype of different cultures of $P$. rubescens CYA 18 (deposited as strain PCC 7821 at the Institut Pasteur): strain PCC 7821 was of genotype GV4a, whereas strain CYA 18 (NIVA Collection) was of genotype GV4b.

P. agardhii group. Of 38 green-coloured strains of Planktothrix, 5 were of genotype GV2a, 23 were of genotype GV5 and 10 were of genotype GV6. Again, the genotypes differed in five of the seven cases where there was more than one isolate from a lake: both GV5 and GV6 occurred in Lakes Fröylandsvatnet, Gjersjøen and Steinsfjorden, and both subclasses of GV5 occurred in Lakes Arungen, Helgetjernet, Gjersjøen and Steinsfjorden. There was a discrepancy in the genotype of $P$. agardhii CYA 29: the culture maintained at Bristol since 1981 was of genotype GV5b (and represented the type strain of genotype GV5), but a culture sampled recently from the NIVA Collection was of genotype GV6. These discrepancies (and those observed in different cultures of $P$. rubescens CYA 18) may indicate that genetic rearrangements had occurred, or that the original isolates contained trichomes of different genotype.

\section{$\boldsymbol{p}_{\mathrm{c}}$ values of gas vesicles}

$p_{\mathrm{c}}$ values were determined for 39 strains, representing most of the species and GV-genotype combinations available from each of the different lakes (Table 3). The principal finding was that the mean $p_{\mathrm{c}}$ was primarily associated with GV-genotype. The range of mean $p_{c}$ for the different genotypes was: GV2, 0.79-0.91 MPa; GV4, 0.76-0.88 MPa; GV5, 0.61-0.75 MPa; GV6, 0.63$0.72 \mathrm{MPa}$. The frequency distribution of mean $p_{\mathrm{c}}$ in GVgenotypes revealed no significant difference between GV2 and GV4, or between GV5 and GV6 (Fig. 3).
However, the difference between the two groups (GV2/4 with a mean $p_{\mathrm{c}}$ of $0.85 \mathrm{MPa}$ and GV5/6 with a mean of $0.65 \mathrm{MPa})$ is highly significant $(t=12 \cdot 9, P<0 \cdot 001)$.

The correlation between $p_{\mathrm{c}}$ and GV-genotype overrides other correlations with species nomenclature or pigmentation. Thus, the only strain of $P$. rubescens with the GV5 genotype has the weaker gas vesicles $\left(p_{c} 0 \cdot 71 \mathrm{MPa}\right)$, whereas all others, of GV2 and GV4, have stronger gas vesicles. Within the green-pigmented strains, three of the $P$. agardhii group are of genotype GV2 and have stronger gas vesicles $\left(p_{\mathrm{c}} 0 \cdot 81-0.92 \mathrm{MPa}\right)$ whereas the rest, of GV5 or GV6, have weaker gas vesicles (Table 3).

\section{DISCUSSION}

\section{Correlations between $\boldsymbol{p}_{\mathrm{c}}$ and GV-genotype}

It has previously been suggested that the length of $g v p C$ may influence the width of gas vesicles and hence their $p_{c}$; strains of Planktothrix of genotype GV3, with several copies of the shorter $g \nu p C^{16}$, produce narrower gas vesicles of higher $p_{\mathrm{c}}$ than those of GV1 and GV2, which have several copies of $g v p C^{20}$ only (Bright \& Walsby, 1999). The results from the Nordic Planktothrix strains extend these correlations: strains of genotype GV4, which have several copies of $g v p C^{20}$ in addition to $g \nu p C^{28}$, produce gas vesicles of the same range of $p_{c}$ as GV2; those of genotypes GV5 and GV6, which have several copies of $g v p C^{28}$ only, have gas vesicles with the lowest range of $p_{\mathrm{c}}$. In Planktothrix strains that contain two variants of $g v p C$ (genotypes GV3 and GV4) these correlations with $p_{\mathrm{c}}$ hold only for the shorter form. An explanation for this may be that more of the shorter gvpC is expressed. In strain Pla 9401 (GV3) it is expected that more $\mathrm{GvpC}^{16}$ than $\mathrm{GvpC}^{20}$ will be produced because there are three copies of $g \nu p C^{16}$ and only one of $g \nu p C^{20}$ (Beard et al., 1999).

\section{Correlations between $\boldsymbol{p}_{\mathrm{c}}$ and lake depth}

Many of the lakes from which the Planktothrix strains had been isolated were formed in glacial basins. The smaller lakes occupy basins of the kettle type or those formed by stream action. The maximum depths are given in Table 3.

We have previously suggested that there has been natural selection in planktonic cyanobacteria for gas vesicles of sufficiently high $p_{\mathrm{c}}$ to withstand the maximum combination of cell turgor pressure $\left(p_{\mathrm{t}}\right)$ and hydrostatic pressure $\left(p_{\mathrm{h}}\right)$ in different lakes (Walsby, 1994; Walsby et al., 1999). The simplistic expectation is that the $p_{\mathrm{c}}$ should be sufficient to withstand the maximum combination of pressures $\left(p_{\mathrm{t}}+p_{\mathrm{h}}\right)$ but should not exceed this combination. During the summer $P$. agardhii tends to occur in the epilimnion and $P$. rubescens in the metalimnion of lakes, at depths not usually exceeding 20 $\mathrm{m}$ (where $p_{\mathrm{h}}=0 \cdot 20 \mathrm{MPa}$ ); during active photosynthesis the $p_{\mathrm{t}}$ may reach $0.4 \mathrm{MPa}$, giving a combined pressure $\left(p_{\mathrm{h}}+p_{\mathrm{t}}\right)$ of $0.6 \mathrm{MPa}$. The mean $p_{\mathrm{c}}$ exceeds this value in all of the strains investigated (Table 3). The first expectation is therefore fulfilled for this period. 
During the autumn and spring, however, Nordic lakes are mixed to their greatest depth (most are dimictic and turn over before and after formation of ice cover); a proportion of the Planktothrix population is then circulated to the lake bottom. During this period $p_{\mathrm{t}}$ is unlikely to exceed $0 \cdot 2 \mathrm{MPa}$. Table 3 lists the depths of the lakes from which the different strains were collected and the maximum combination of $\left(p_{h}+p_{t}\right)$, where $p_{h}$ is calculated from the greatest depth (9810 $\mathrm{Pa} \mathrm{m}^{-1}$ at $\left.4{ }^{\circ} \mathrm{C}\right)$ and $p_{\mathrm{t}}$ is assumed to be $0.2 \mathrm{MPa}$. Again, the mean $p_{\mathrm{c}}$ exceeds $\left(p_{\mathrm{t}}+p_{\mathrm{h}}\right)$ for strains from all of the lakes except the $P$. agardhii strains in the $64 \mathrm{~m}$ deep Lake Gjersjøen and the $67 \mathrm{~m}$ deep Gulf of Finland. For these strains, trichomes circulating below a depth of $50 \mathrm{~m}$ will lose buoyancy; they will be lost to the bottom sediment and will not contribute to the spring inoculum. The selection of strains with stronger gas vesicles depends on the relative costs of their production and the benefits they provide in decreasing these losses (see Walsby et al., 1999, for a more detailed discussion). Of particular interest here is the occurrence of strains whose gas vesicle genotype is atypical for their species but is correlated with lake depth: $P$. agardhii CYA 91 has genotype GV2, which confers the medium $p_{\mathrm{c}}$ of 0.92 $\mathrm{MPa}$, sufficient to withstand the $\left(p_{\mathrm{h}}+p_{\mathrm{t}}\right)$ of $0.84 \mathrm{MPa}$ at the greatest depth, $64 \mathrm{~m}$, in Lake Mälaren. Of the other two strains of $P$. agardhii with genotype GV2, strain 127 $\left(p_{\mathrm{c}}=0.85 \mathrm{MPa}\right.$ ) occurs in the moderately deep Vesijärvi $(40 \mathrm{~m})$ and strain $88 / 1\left(p_{\mathrm{c}}=0.81 \mathrm{MPa}\right)$ in the shallower Lake Ören $(25 \mathrm{~m})$.

Concerning the second expectation, provision of $p_{\mathrm{c}}$ that does not exceed requirements, it is first noted that Planktothrix strains of genotype GV3 with the highest $p_{c}$ values (the dominant form in the $136 \mathrm{~m}$ deep Lake Zürich) are absent from all of the Nordic lakes investigated. We suggest that the strains of genotype GV3 are restricted in occurrence to the deepest lakes, like Lake Zürich. Six of the Nordic lakes contained strains of $P$. rubescens with genotype GV2/4 that have gas vesicles whose $p_{c}$ exceeds that required during winter mixing by $0.4 \mathrm{MPa}$ or more (Table 3 ). There is, though, one exception: P. rubescens CYA 87 has the atypical genotype GV5 and gas vesicles of lower $p_{\mathrm{c}}$; it occurs in the shallow Lake Levrasjøn $(15 \mathrm{~m})$. This exception shows that the association between the GV2/4 genotype and the red strains, although strong, is not obligatory. Possible reasons why red strains with the GV5/6 genotype have not been selected in other lakes include the following: (1) insufficient time has occurred for selection since development of the population in the lake; (2) the benefit in reducing costs is insufficient; (3) the GV5/6 genotype is linked with other characters that are counterselective in these lakes; (4) the turgor pressures might be higher than $0.2 \mathrm{MPa}$ in the red forms during periods of deep circulation; (5) the strains in culture are not all representative of the population in the lakes $(P$. rubescens of genotypes GV2 and GV5 occur in Levrasjøn).

Several lakes of different depths were shown to contain Planktothrix strains of both the GV2/4 and GV5/6 genotypes. This suggests that there is competition between strains producing the two types of gas vesicles: there should be selection for strains of genotype GV2/4, producing the stronger gas vesicles, following mixing events beyond $60 \mathrm{~m}$; and there may be enrichment for strains of genotype GV5/6, producing the more efficient weaker gas vesicles, during summer growth in the metalimnion or epilimnion. This can now be investigated quantitatively by using the diagnostic PCR described in this paper to identify the GV-genotype of individual Planktothrix trichomes in lakewater samples.

\section{ACKNOWLEDGEMENTS}

We thank Mrs Randi Skulberg for providing Planktothrix strains, Mrs Annette Richer for assistance in maintaining cultures and Mr Tim Colburn for drawing Figs 1a and 2. This work was supported by a grant, GR3/10970, and a research studentship (to P.A.D.), from the Natural Environment Research Council.

\section{REFERENCES}

Anagnostides, K. \& Komàrek, J. (1988). Modern approaches to the classification system of cyanophytes. 3. Oscillatoriales. Arch Hydrobiol 80, 327-472.

Beard, S. J., Handley, B. A., Hayes, P. K. \& Walsby, A. E. (1999). The diversity of gas vesicle genes in Planktothrix rubescens from Lake Zürich. Microbiology 145, 2757-2768.

Bright, D. I. \& Walsby, A. E. (1999). The relationship between critical pressure and width of gas vesicles in isolates of Planktothrix rubescens from Lake Zürich. Microbiology 145, 2769-2775.

Bright, D. I. \& Walsby, A. E. (2000). The daily integral of growth by Planktothrix rubescens calculated from growth rate in culture and irradiance in Lake Lake Zürich. New Phytol 146, 301-316.

Damerval, T., Houmard, J., Guglielmi, G., Csiszàr, K. \& Tandeau de Marsac, N. (1987). A developmentally regulated gvpABC operon is involved in the formation of gas vesicles in the cyanobacterium Calothrix 7601. Gene 54, 83-92.

DasSarma, S., Arora, P., Lin, F., Molinari, E. \& Yin, L. R.-S. (1994). Wild-type gas vesicle formation requires at least ten genes in the gvp gene cluster of Halobacterium halobium plasmid pNRC100. J Bacteriol 176, 7646-7652.

Griffiths, A. E. (1992). Gas vesicle proteins in cyanobacteria. $\mathrm{PhD}$ thesis, University of Bristol.

Griffiths, A. E., Walsby, A. E. \& Hayes, P. K. (1992). The homologies of gas vesicle proteins. J Gen Microbiol 138, 1243-1250.

Hayes, P. K. \& Powell, R. S. (1995). The gvpA/C cluster of Anabaena flos-aquae has multiple copies of a gene encoding GvpA. Arch Microbiol 164, 50-57.

Hayes, P. K., Walsby, A. E. \& Walker, J. E. (1986). Complete amino acid sequence of cyanobacterial gas-vesicle protein indicates a 70 residue molecule that corresponds in size to the crystallographic unit cell. Biochem J 236, 31-36.

Hayes, P. K., Lazarus, C. M., Bees, A., Walker, J. E. \& Walsby, A. E. (1988). The protein encoded by $g v p C$ is a minor component of gas vesicles isolated from the cyanobacteria Anabaena flos-aquae and Microcystis sp. Mol Microbiol 2, 545-552.

Hayes, P. K., Buchholz, B. \& Walsby, A. E. (1992). Gas vesicles are strengthened by the outer-surface protein, GvpC. Arch Microbiol 157, 229-234.

Offner, S., Wanner, G. \& Pfeifer, F. (1996). Functional studies of 
the gvpACNO operon of Halobacterium salinarium reveal that the GvpC protein shapes gas vesicles. J Bacteriol 178, 2071-2078.

Rippka, R. (1988). Isolation and purification of cyanobacteria. Methods Enzymol 167, 3-27.

Skulberg, O. M. \& Skulberg, R. (1985). Planktic species of Oscillatoria (Cyanophyceae) from Norway. Characterization and classification. Arch Hydrobiol Suppl 71, 157-174.

Skulberg, R. \& Skulberg, O. M. (1990). Research with Algal Cultures-NIVA's Culture Collection of Algae. Oslo: Norsk Institutt for Vannforskning. ISBN 82-577-1743-6.

Tandeau de Marsac, N., Mazel, D., Bryant, D. A. \& Houmard, J. (1985). Molecular cloning and nucleotide sequence of a developmentally regulated gene from the cyanobacterium Calothrix PCC 7601: a gas vesicle protein gene. Nucleic Acids Res 13, 7223-7236.

Utkilen, H. C., Skulberg, O. M. \& Walsby, A. E. (1985). Buoyancy regulation and chromatic adaptation in planktonic Oscillatoria species: alternative strategies for optimising light absorption in stratified lakes. Arch Hydrobiol 104, 407-417.

Walker, J. E. \& Walsby, A. E. (1983). Molecular weight of gasvesicle protein from the planktonic cyanobacterium Anabaena flos-aquae and implications for structure of the vesicle. Biochem J 209, 809-815.

Walsby, A. E. (1973). A portable apparatus for measuring relative gas vacuolation, the strength of gas vacuoles, and turgor pressure in planktonic blue-green algae and bacteria. Limnol Oceanogr 18, 653-658.

Walsby, A. E. (1981). Cyanobacteria: planktonic gas-vacuolate forms. In The Prokaryotes, pp. 224-235. Edited by M. Starr, H. Stolp, H. Trüper, A. Balows and H. G. Schlegel. New York: Springer.

Walsby, A. E. (1994). Gas vesicles. Microbiol Rev 58, 94-114.

Walsby, A. E. \& Bleything, A. (1988). The dimensions of cyanobacterial gas vesicles in relation to their efficiency in providing buoyancy and withstanding pressure. J Gen Microbiol 134, 2635-2645.

Walsby, A. E. \& Hayes, P. K. (1988). The minor cyanobacterial gas vesicle protein, GVPc, is attached to the outer surface of the gas vesicle. J Gen Microbiol 134, 2647-2657.

Walsby, A. E., Avery, A. \& Schanz, F. (1998). The critical pressures of gas vesicles in Planktothrix rubescens in relation to the depth of winter mixing in Lake Zürich, Switzerland. J Plankton Res 20, 1357-1375.

Walsby, A. E., Beard, S. J. \& Hayes, P. K. (1999). The natural selection of gas vesicles. In The Phototrophic Prokaryotes, pp. 633-646. Edited by G. Peschek, W. Löffelhardt \& G. Schmetterer. Dordrecht: Kluwer Academic.

Received 17 January 2000; revised 7 March 2000; accepted 22 May 2000. 